\title{
Analysis of Essential Oil Composition of Thymbra spicata var. spicata: Antifungal, Antibacterial and Antimycobacterial Activities
}

Turgut Kılıç

University of Balıkesir, Art \& Science Faculty, Department of Chemistry, 10100, Balıkesir, Turkey. Fax: +902662493360. E-mail: turmetbal@yahoo.com.tr

Z. Naturforsch. 61c, 324-328 (2006); received October 28/December 12, 2005

The fresh leaves and brine of leaves of Thymbra spicata var. spicata (KARAKIZ ${ }^{\mathrm{TM}}$ ) were analyzed by hydrodistillation, headspace and GC/MS techniques. The main components were determined as carvacrol, $p$-cymene, $\beta$-myrcene, $\gamma$-terpinene, $\alpha$-terpinene and trans-caryophyllene. The essential oil and the main compounds, carvacrol and trans-caryophyllene, have been tested against E. coli, S. epidermidis, B. subtilis, S. aureus, S. typhimurium, K. pneumoniae, $P$. aeruginosa, E. faecalis and $C$. albicans. While the essential oil and carvacrol showed strong activity against all microorganisms, except $P$. aeruginosa, trans-caryophyllene showed activity only against $C$. albicans. The essential oil and carvacrol also showed strong antimycobacterial activity.

Key words: Thymbra spicata, Carvacrol, Antimicrobial and Antimycobacterial Activity

\section{Introduction}

Two species and four taxa from the Thymbra species in Turkey are reported (Davis, 1982). The species have been used as an antiseptic, stimulant, against common cold and as herbal tea and brine in breakfast and on salads especially in the western part of Turkey (Muller-Riebau et al., 1997; Tümen et al., 1994).

The first report concerning antimicrobials in the Thymbra species in Turkey was on 6-hydroxyflavones (Miski et al., 1983). The essential oil composition and antibacterial and antifungal activities of species were reported by various groups (Tümen et al., 1994; Baser et al., 1996; Yegen et al., 1992), and one study reported antioxidant activity of Turkish Thymbra spicata (Kosar et al., 2003). Insecticidal activity has been reported against Sitophilus oryzae adults and the last instars of Ephestia kuehniella (Sarac and Tunc, 1995a, b).

In this study, the essential oil obtained from $T$. spicata was analyzed for its chemical compostion, and then antifungal and antibacterial activities including antimycobacterial activity were investigated. Commercial thyme brine (KARAKIZ ${ }^{\mathrm{TM}}$ ) was also analyzed. This is the first report on antimycobacterial activity of Thymbra spicata oil and its main components.

\section{Experimental}

\section{Plant material}

Thymbra spicata var. spicata was collected from Torbal1-İzmir on May 15, 2004. The plant was identified by Professor G. Tumen of Balıkesir University, Turkey. A voucher specimen was deposited in the Herbarium of the Department of Biology, Faculty of Arts and Science, Balıkesir University. Brine of T. spicata (KARAKIZ ${ }^{\mathrm{TM}}$ ) was purchased from local markets in İstanbul.

\section{Chemical analysis}

$170 \mathrm{~g}$ of fresh leaves of Thymbra spicata var. spicata were subjected to a Clevenger type apparatus for $3 \mathrm{~h} .5 .3 \mathrm{~mL}$, a yield of $3.1 \%(\mathrm{v} / \mathrm{w})$, of essential oil were obtained. It was dried over anhydrous $\mathrm{CaCl}_{2}$ and stored at $+4{ }^{\circ} \mathrm{C}$.

\section{GC/MS and headspace conditions}

GC/MS was carried out on a Thermo Electron Trace 2000 GC model gas chromatograph and Thermo Electron DSQ quadrupole mass spectrometer. A non-polar Phenomenex DB-5 fused silica column $(60 \mathrm{~m} \times 0.25 \mathrm{~mm}$ i.d. with $0.5 \mu \mathrm{m}$ film thickness) was used with helium at $1 \mathrm{~mL} / \mathrm{min}$ $(0.14 \mathrm{MPa})$ as a carrier gas and a polar Innowax FSC column $(60 \mathrm{~m} \times 0.25 \mathrm{~mm}$ i.d. with $0.5 \mu \mathrm{m}$ film thickness) was also used. The GC oven tempera- 
ture was kept at $60^{\circ} \mathrm{C}$ for $10 \mathrm{~min}$ and programmed to $220^{\circ} \mathrm{C}$ at a rate of $4{ }^{\circ} \mathrm{C} / \mathrm{min}$ and then kept constant at $220^{\circ} \mathrm{C}$ for $15 \mathrm{~min}$. The split ratio was adjusted to $1: 20$, the injection volume was $0.1 \mu \mathrm{L}$. EI/MS spectra were recorded at $70 \mathrm{eV}$ ionization energy. Mass range was $m / z$ 35-500 amu. Alkanes were used as reference in the calculation of Kovats indices (KI). The identification of the compounds was based on the comparison of their retention times and mass spectra with those obtained from authentic samples and/or the NIST and Wiley spectra as well as the literature data (Adams, 1995). A Thermo AC 2000 headspace instrument was used for headspace analysis, the program and conditions of which were as follows: The vial oven temperature was $120{ }^{\circ} \mathrm{C}$ for each analysis and injection volume was $10 \mu \mathrm{L}$. Details are as given in our previous work (Goren et al., 2004).

\section{Antibacterial and antifungal activity}

The essential oil of T. spicata, $\alpha$-pinene, $\beta$-pinene, carvacrol and trans-caryophyllene were tested against standard bacterial strains such as E. coli ATCC 29995, S. epidermidis ATCC 12228, B. subtilis ATCC 6633, S. aureus ATCC 6538P, S. typhimurium, K. pneumoniae CCM 2318, P. aeruginosa ATCC 27853, E. faecalis ATCC 29212, and the yeast $C$. albicans ATCC 10239. The agar diffusion method was used to determine the inhibition zones of the tested compounds and esssential oil against standard bacterial strains. Essential oil and the compounds with inhibition zones higher than $7 \mathrm{~mm}$ were selected to determine the antimicrobial activity quantitatively as minimum inhibition concentration (MIC). The broth microdilution method was applied for this purpose (Goren et al., 2003, 2004; Kıliç et al., 2005; NCCLS, 1990). The antibacterial and antifungal activity tests were done as three replicates for each organism and RSD \% value was less than 1.5 .

\section{Screening for antimycobacterial activity}

Mycobacterium smegmatis ATCC 14468, from freshly grown cultures, was used to obtain suspensions of 0.5 McFarland turbidity. A cotton swab was wetted with the suspension and the microorganism was spread over Mueller Hinton agar plates. Wells, $6 \mathrm{~mm}$ in diameter, were punched into the agar, and $20 \mu \mathrm{l}$ of samples were applied into these wells. Pure DMSO and sterile water were used as controls. The plates were incubated at $37^{\circ} \mathrm{C}$ for $3 \mathrm{~d}$ until a growth was clearly observed. The inhibition zones around the wells were measured and photographed (Kilıç et al., 2005; NCCLS, 1990). The antimycobacterial activity tests were done as three replicates for each organism and RSD \% value was less than 1.5 .

\section{Determination of MIC values for selected species of Mycobacteria}

Suspensions of $0.5 \mathrm{McFarland}$ turbidity were prepared from freshly grown cultures of $M$. smegmatis ATCC 14468, M. terrae ATCC 15755, M. intracellulare ATCC 139450 and M. tuberculosis H37Ra ATCC 25177 in Tween 80 containing water. The components were diluted using Middlebrook $7 \mathrm{H} 9$ broth and mycobacteria were inoculated. The tubes were incubated at $37{ }^{\circ} \mathrm{C}$ and checked daily until growth was observed. The lowest concentration of drug that inhibited the growth was considered as MIC value.

\section{Results and Discussion}

$5.3 \mathrm{~mL}$ essential oil were obtained from $170 \mathrm{~g}$ of dry T. spicata var. spicata leaves in a yield of 3.1\% and its density was $d^{22}=0.898 \mathrm{~g} / \mathrm{mL}$. Commercial thyme brine "KARAKIZTM" was used for the analysis of brine of Thymbra spicata which was placed in brine in 2002 and 2003. Essential oil of fresh leaves of the species was analyzed by $\mathrm{GC} /$ MS, while the composition of thyme brine was determined by headspace GC/MS. Twenty - nine components were identified representing about $97.8 \%$ of the oil. The main compounds were identified as carvacrol $(34.9 \%), \gamma$-terpinene $(25.6 \%)$, $p$-cymene $(9.1 \%), \alpha$-terpinene $(6.9 \%)$, thujene $(5.2 \%)$, trans-caryophyllene $(5.1 \%)$ and $\beta$-myrcene $(4.8 \%)$ (Table I). Analysis of the dried leaves and brine of T. spicata by headspace GC/MS indicated the presence of the same main compounds as observed in the essential oil (Table I). According to these results, we concluded that the brine of Thymbra spicata preserves its active composition at least two years.

The essential oil of fresh leaves of T. spicata and and pure compounds; $\alpha$-pinene, $\beta$-pinene, carvacrol and trans-caryophyllene were tested against standard bacterial strains (Table II). The essential oil showed activity against all the tested bacteria and fungi. MIC values of essential oil were deter- 
Table I. Composition of essential oil of Thymbra spicata var. spicata and its brine.

\begin{tabular}{lccccccc}
\hline Compound & $\mathrm{KI}^{*}$ & $\mathrm{KI}^{\dagger}$ & $\mathrm{a} \%$ & $\mathrm{~b} \%$ & $\mathrm{c} \%$ & $\mathrm{~d} \%$ & Identification $^{*}$ \\
\hline Methyl isovalerate & 789 & 885 & 0.2 & 0.3 & 0.1 & $\mathrm{t}^{\S}$ & $\mathrm{MS}$ \\
Thujene & 935 & 1031 & 5.2 & 4.8 & $\mathrm{t}$ & $\mathrm{t}$ & MS \\
$\alpha$-Pinene & 941 & 1030 & 1.5 & 3.1 & 0.4 & 4.6 & MS, Co, KI \\
Camphene & 954 & 1074 & 0.2 & 0.4 & 0.7 & 1.0 & MS, Co, KI \\
Sabinene & 978 & 1132 & $\mathrm{t}$ & $\mathrm{t}$ & $\mathrm{t}$ & $\mathrm{t}$ & MS, KI \\
$\beta$-Pinene & 981 & 1120 & 0.4 & 0.7 & $\mathrm{t}$ & $\mathrm{t}$ & MS, Co, KI \\
$\beta$-Myrcene & 994 & 1175 & 4.8 & 7.7 & 5.7 & 6.7 & MS, Co, KI \\
$\alpha$-Phellandrene & 1007 & 1177 & 0.8 & 1.2 & 0.4 & 1.1 & MS, KI \\
$\Delta^{3}$-Carene & 1015 & 1168 & $\mathrm{t}$ & $\mathrm{t}$ & $\mathrm{t}$ & $\mathrm{t}$ & MS, KI \\
$\alpha$-Terpinene & 1020 & 1188 & 6.9 & 10.1 & 6.2 & 9.9 & MS, KI \\
$p$-Cymene & 1028 & 1281 & 9.1 & 12.3 & 26.0 & 21.0 & MS, Co, KI \\
DL-Limonene & 1031 & 1204 & $\mathrm{t}$ & $\mathrm{t}$ & - & $\mathrm{t}$ & MS, Co, KI \\
$\beta$-Phellandrene & 1032 & 1218 & 0.8 & 1.0 & 0.3 & $\mathrm{t}$ & MS, KI \\
1,8-Cineole & 1035 & 1214 & $\mathrm{t}$ & $\mathrm{t}$ & $\mathrm{t}$ & $\mathrm{t}$ & MS, Co, KI \\
$\gamma$-Terpinene & 1062 & 1255 & 25.6 & 30.1 & 31.2 & 30.1 & MS, Co, KI \\
$\alpha$-Terpinolone & 1091 & 1291 & 0.3 & 0.2 & 1.4 & 0.7 & MS, Co, KI \\
1,3,5- $p$-Menthatriene & 1125 & 1105 & $\mathrm{t}$ & $\mathrm{t}$ & $\mathrm{t}$ & $\mathrm{t}$ & MS, KI \\
Terpinen-4-ol & 1179 & 1607 & 0.9 & 0.1 & 0.4 & 0.4 & MS, KI \\
Thymol & 1294 & 2205 & 0.2 & $\mathrm{t}$ & $\mathrm{t}$ & $\mathrm{t}$ & MS, Co, KI \\
Carvacrol & 1300 & 2246 & 34.9 & 23.4 & 25.6 & 20.1 & MS, Co, KI \\
trans-Caryophyllene & 1420 & 1613 & 5.1 & 0.6 & 0.8 & 1.0 & MS, Co, KI \\
Aromadendrene & 1444 & 1628 & $\mathrm{t}$ & $\mathrm{t}$ & $\mathrm{t}$ & $\mathrm{t}$ & MS, KI \\
$\alpha$-Humulene & 1458 & 1686 & 0.3 & $\mathrm{t}$ & $\mathrm{t}$ & $\mathrm{t}$ & MS, KI \\
$\gamma$-Muurolone & 1478 & 1711 & 0.2 & $\mathrm{t}$ & $\mathrm{t}$ & $\mathrm{t}$ & MS, KI \\
$\beta$-Bisabolene & 1513 & 1741 & $\mathrm{t}$ & $\mathrm{t}$ & $\mathrm{t}$ & $\mathrm{t}$ & MS, KI \\
Ledene & 1518 & 1708 & 0.1 & $\mathrm{t}$ & $\mathrm{t}$ & $\mathrm{t}$ & MS, KI \\
$\delta$-Cadinene & 1525 & 1770 & 0.1 & $\mathrm{t}$ & $\mathrm{t}$ & $\mathrm{t}$ & MS, KI \\
Spathulenol & 1581 & 2120 & 0.1 & 0.1 & 0.2 & $\mathrm{t}$ & MS, KI \\
Caryophyllene oxide & 1585 & 1994 & 0.1 & $\mathrm{t}$ & $\mathrm{t}$ & $\mathrm{t}$ & MS, Co, KI \\
\hline Total & & & 97.8 & 96.1 & 99.4 & 96.6 & \\
\hline GC & & & & & &
\end{tabular}

GC/MS analyses were replicated three times (mean RSD \% value is 0.1 ).

* Phenomenex DB-5 column. ${ }^{\dagger}$ Innowax FSC column. ${ }^{\star}$ MS, mass spectrometry. Co, co-injection. KI, Kovats indices. $\S_{\mathrm{t}}$, trace (less than $0.1 \%$ ).

a, Essential oil of Thymbra spicata var. spicata; b, leaves, collected in May 2005, analyzed by headspace GC/MS; c, KARAKIZ ${ }^{\mathrm{TM}}$ brine, produced in 2002 , analyzed by headspace GC/MS; d, KARAKIZ ${ }^{\mathrm{TM}}$ brine, produced in 2003 , analyzed by headspace GC/MS.

Table II. Antibacterial and antifungal activity of essential oil of T. spicata var. spicata and its pure compounds ${ }^{\mathrm{a}}$.

\begin{tabular}{|c|c|c|c|c|c|c|c|c|c|}
\hline Compound & E. coli & $\begin{array}{l}\text { S. epider- } \\
\text { midis }\end{array}$ & B. subtilis & S. aureus & $\begin{array}{l}\text { S. typhi- } \\
\text { murium }\end{array}$ & $\begin{array}{l}\text { K. pneu- } \\
\text { moniae }\end{array}$ & $\begin{array}{l}\text { P. aerugi- } \\
\text { nosa }\end{array}$ & $\begin{array}{l}\text { E. fae- } \\
\text { calis }\end{array}$ & $\begin{array}{l}\text { C. albi- } \\
\text { cans }\end{array}$ \\
\hline T. spicata var. spicata & $<0.47$ & 0.94 & $<0.47$ & 0.94 & $<0.47$ & 0.94 & $\mathrm{NA}^{\mathrm{b}}$ & $<0.47$ & 3.75 \\
\hline$\alpha$-Pinene & 0.94 & 0.94 & 7.5 & 0.47 & 0.94 & 7.5 & NA & 0.94 & 7.5 \\
\hline$\beta$-Pinene & NA & NA & NA & NA & NA & NA & NA & NA & NA \\
\hline Carvacrol & $<0.47$ & $<0.47$ & $<0.47$ & $<0.47$ & $<0.47$ & $<0.47$ & 1.88 & $<0.47$ & 0.94 \\
\hline trans-Caryophyllene & 0.94 & $\mathrm{NT}^{\mathrm{c}}$ & 1.88 & 0.94 & NT & NA & NA & NA & 1.88 \\
\hline Gentamycin $^{\mathrm{d}}$ & 0.97 & 7.8 & 0.97 & 0.48 & 0.48 & 0.48 & 0.97 & 3.1 & NT \\
\hline Fluconazole $^{\mathrm{d}}$ & NT & NT & NT & NT & NT & NT & NT & NA & 15.6 \\
\hline
\end{tabular}

${ }^{a}$ MIC values are given as mg/L. ${ }^{b}$ NA, non-active. ${ }^{c}$ NT, not tested. ${ }^{d}$ Gentamycin and fluconazole are used as positive controls and results are given as $\mu \mathrm{g} / \mathrm{mL}$.

mined as $<0.47 \mathrm{mg} / \mathrm{L}$ against E. coli, B. subtilis, S. typhimurium and E. faecalis, $0.94 \mathrm{mg} / \mathrm{L}$ against S. epidermidis, S. aureus, K. pneumoniae, and $3.75 \mathrm{mg} / \mathrm{L}$ against $C$. albicans. The essential oil of
T. spicata var. spicata did not show activity against P. aeruginosa (Table II).

The most active compound was carvacrol with a MIC value less than $0.47 \mathrm{mg} / \mathrm{L}$, except for $P$. aeru- 
Table III. Antimycobacterial activity of essential oil of T. spicata var. spicata and its pure components ${ }^{\mathrm{a}}$.

\begin{tabular}{lllll}
\hline Tested material & M. smegmatis & M. terrae & M. intracellulare & M. tuberculosis \\
\hline Essential oil of T. spicata & 256 & 128 & 512 & NT $^{\mathrm{c}}$ \\
$\alpha$-Pinene & $1024(7.51)$ & $256(1.88)$ & $256(1.88)$ & $128(0.94)$ \\
$\beta$-Pinene & NA $^{\mathrm{b}}$ & $\mathrm{NA}$ & $\mathrm{NA}$ & $\mathrm{NT}$ \\
trans-Caryophyllene & $512(2.5)$ & $1024(5.0)$ & $\mathrm{NA}$ & $512(5.0)$ \\
Carvacrol & $64(0.42)$ & $128(0.85)$ & $128(0.85)$ & $64(0.42)$ \\
Rifampicind & $\mathrm{NT}$ & $\mathrm{NT}$ & $\mathrm{NT}$ & $0.5\left(6.1 \times 10^{-4}\right)$ \\
\hline
\end{tabular}

${ }^{a} \mathrm{MIC}$ values are given as $\mu \mathrm{g} / \mathrm{mL}$ (mM). ${ }^{\mathrm{b}} \mathrm{NA}$, non-active. ${ }^{\mathrm{c}} \mathrm{NT}$, not tested. ${ }^{\mathrm{d}}$ Rifampicin is used as positive control and results are given as $\mu \mathrm{g} / \mathrm{mL}$.

ginosa $(1.88 \mathrm{mg} / \mathrm{L})$ and C. albicans $(0.94 \mathrm{mg} / \mathrm{L}) . \alpha-$ Pinene showed activity against the tested bacteria with the following MIC values: $0.47 \mathrm{mg} / \mathrm{L}$ against $S$. aureus, $0.94 \mathrm{mg} / \mathrm{L}$ against $E$. coli, $S$. epidermidis, S. typhimurium and E. faecalis and $7.5 \mathrm{mg} / \mathrm{L}$ against $K$. pneumoniae, $B$. subtilis and $C$. albicans. However, in contrast to $\alpha$-pinene, $\beta$-pinene did not show activity against all tested bacteria and fungi. Moreover, trans-caryophyllene showed activity only against $E$. coli, S. aureus, B. subtilis and $C$. albicans, with MIC values of $0.94,0.94,1.88$, $1.88 \mathrm{mg} / \mathrm{L}$, respectively. Gentamycin and fluconazole were used as positive controls.

The antimycobacterial activity of essential oil of T. spicata and its components $\alpha$-pinene, $\beta$-pinene, trans-caryophyllene and carvacrol was tested against Mycobacterium smegmatis, M. terrae, $M$. intracellulare and M. tuberculosis. The MIC values for the essential oil were found to be 256, 128,

Adams R. (1995), The leaf oils and chemotaxonomy of Juniperus sect. Juniperus. Biochem. Syst. Ecol. 26, 637-645.

Baser K. H. C., Ermin N., Özek T., Tümen G., and Karaer F. (1996), The essential oil of Thymbra sintenisii Bornm. et Aznav subsp. Isaurica P. H. Davis and Origanum leptocladum Boiss. J. Essent. Oil Res. 8, 699701.

Davis P. H. (1982), Flora of Turkey and The East Aegean Islands, Vol. 7. Edinburgh University Press, Edinburgh.

Goren A. C., Bilsel G., Bilsel M., Demir H., and Kocabas E. E. (2003), Analysis of essential oil of Coridothymus capitatus (L.) and its antibacterial and antifungal activity. Z. Naturforsch. 58c, 687-690.

Goren A. C., Topçu G., Bilsel G., Bilsel M., Wilkinson J. M., and Cavanagh H. M. (2004), Analysis of essential oil of Satureja thymbra by hydrodistillation, ther-
$512 \mu \mathrm{g} / \mathrm{mL}$, respectively (Table III). The essential oil was not tested against $M$. tuberculosis. The pure compound $\alpha$-pinene showed activity against all mycobacteria. The MIC values were found to be 1024, 256, 256 and $128 \mu \mathrm{g} / \mathrm{mL}$, respectively. However, $\beta$-pinene did not show activity against all mycobacteria. The main compound carvacrol showed activity against $M$. smegmatis, M. terrae, M. intracellulare and M. tuberculosis with MIC values of $64,128,128$ and $64 \mu \mathrm{g} / \mathrm{mL}$, respectively. trans-Caryophyllene showed activity only against M. smegmatis $(512 \mu \mathrm{g} / \mathrm{mL})$ and M. terrae $(1024 \mu \mathrm{g} /$ $\mathrm{mL})$ (Table III).

\section{Acknowledgements}

The author wish to thank Mr. Sabri Özgenç for his financial support to this study and Assoc. Prof. Dr. Ahmet Ceyhan Gören for his help.

mal desorber and headspace GC/MS techniques and its antimicrobial activity. Nat. Prod. Res. 18, 189-195.

Kılıç T., Dirmenci T., Satil F., Bilsel G., Kocagoz T., Altun M., and Goren A. C. (2005), Fatty acid compositions of seed oils of three Turkish Salvia species and biological activities. Chem. Nat. Compd. 41, 276-279.

Kosar M., Dorman H. J. D., Bachmayer O., Baser K. H. C., and Hiltunen R. (2003), An improved on-line HPLC-DPPH method for the screening of free radical scavenging compounds in water extracts of Lamiaceae plants. Chem. Nat. Compd. 39, 161-166.

Miski M., Ulubelen A., and Mabry T. J. (1983), 6-Hydroxyflavones from Thymbra spicata. Phytochemistry 22, 2093-2099.

Muller-Riebau F. J., Berger M., Yegen O., and Çakir C. (1997), Seasonal variations in the chemical compositions of essential oils of selected aromatic plants growing wild in Turkey. J. Agr. Food. Chem. 45, 48214825 . 
National Committee for Clinical Laboratory Standards (1990), Methods for Dilution Antimicrobial Susceptibility Test for Bacteria that Grow Aerobically. Approved Standard M7-A2 1990. NCCLS, Villanova, PA.

Sarac A. and Tunc I. (1995a), Toxicity of essential oil vapors to stored product insects. Z. Pflanzenkr. Pflanzenschutz 102, 69-71.

Sarac A. and Tunc I. (1995b), Residual toxicity and repellency of essential oils to stored product insects. Z. Pflanzenkr. Pflanzenschutz 102, 429-434.
Tümen G., Ermin N., Özek T., Kürkçüoğlu M., and Başer K. H. C. (1994), The composition of essential oils from two varieties of Thymbra spicata L. J. Essent. Oil. Res. 6, 463-468.

Yegen O., Berger B., and Heitefuss R. (1992), Investigations on the fungitoxicity of extracts of 6 selected plants from Turkey against phytopathogenic fungi. $Z$. Pflanzenkr. Pflanzenschutz 99, 349-354. 